\title{
Economic Analysis of Vegetable Production in Arnia Block of Jammu District of Jammu and Kashmir Union Territory
}

\author{
Rigzin Disket ${ }^{1}$, Anil Bhat ${ }^{1 *}$, Jyoti Kachroo ${ }^{1}$, Manish K. Sharma ${ }^{2}$, B.C. Sharma ${ }^{3}$, \\ Bharat Bhushan ${ }^{4}$ and Malika Sharma ${ }^{1}$
}

\author{
${ }^{1}$ Division of Agricultural Economics and ABM, SKUAST-Jammu, India \\ ${ }^{2}$ Division of Statistics and Computer Science, SKUAST-Jammu, India \\ ${ }^{3}$ Division of Agronomy, SKUAST-Jammu, India \\ ${ }^{4}$ Office of the Registrar (Academics), SKUAST-Jammu, India
}

*Corresponding author: drbhatanil@gmail.com (ORCID ID: 0000-0002-4806-9467)

Paper No. 916

Received: 19-04-2021

Revised: 20-06-2021

Accepted: 20-07-2021

\begin{abstract}
The present study attempts to identify the Economic analysis of vegetable production in Arnia block of Jammu district of Jammu and Kashmir Union Territory. The study was conducted in Arnia blocks of Jammu district. Data for the study was collected from a sample of 24 vegetable growers. Farmers in the Arnia block grew three major crops: cabbage, cauliflower, and tomatoes. The findings revealed that, of all the inputs used, the spending on human labour was the greatest. The results regarding cost structure of vegetable cultivation in Arnia block witnessed the largest cost which is incurred in tomato growing and the lowest cost was incurred in cabbage cultivation. The total cost of cultivations in the Arnia block was highest in tomato and lowest in cauliflower. The tomato yielded the highest gross return, while cabbage yielded the lowest. The total gross income from all of the veggies was ₹ 121416.66 per hectare. The highest net returns per hectare was observed in tomatoes, while the lowest was observed in cabbage. The cost-benefit ratio was highest for tomato and lowest for cabbage. In Arnia block farmers follows channel- I to sell their produce in the market such as tomato, cabbage, and cauliflower. The container expense ate up the majority of the marketing cost. Aside from that, transportation expenditures made up a considerable portion of the producer's marketing costs. Retailer's received highest margins in tomatoes, while cauliflower received the lowest at retailer level. Tomatoes have the highest producer share in consumer rupee, whereas cauliflower has the lowest. The total marketing margin was highest in cauliflower, while it was observed lowest tomato. Transportation costs accounted up the majority of marketing costs at the producer and retailer levels.

\section{HIGHLIGHTS}

( Tomato yielded highest gross returns among all the vegetables cultivated in Arnia Block of Jammu district.

(0 Transportation costs in all the vegetable crops accounted up the majority of marketing costs at the producer and retailer levels.

0 Producer's Share in consumer's rupee was found to be highest in Tomato.
\end{abstract}

Keywords: Vegetables, surplus, farmers income, marketing, channel

Vegetable production in India is increasing day by day and has placed India as the second largest producer in the world with approximately 132 million metric tons of fresh vegetables (Anonymous, 2019), Among the vegetables, tomatoes are the leading vegetables based on global production volume. The other major vegetable producing countries are the USA (29.99 MMT), Turkey (25.33
MMT), Vietnam (16.97 MMT), Nigeria (16.67 MMT), Egypt (15.42 MMT), Mexico (15.23 MMT), Russian Federation (14.15 MMT) and Spain (13.26 MMT) (Shahbandeh, 2021). Worldwide agricultural

How to cite this article: Disket, R., Bhat, A., Kachroo, J., Sharma, M.K., Sharma, B.C., Bhushan, B. and Sharma, M. 2021. Economic Analysis of Vegetable Production in Arnia Block of Jammu District of Jammu and Kashmir Union Territory. IJAEB, 14(03): 329-334.

Source of Support: None; Conflict of Interest: None 
development have to face some extraordinary challenges due to growth in the world population, which will cross 8 billion marks after 2023 and about 800 million people will not have enough food to eat. Indian population is also increasing steadily and is already crossed 1,393 millions on July 5, 2021 (Worldometer, 2021). In India, different varieties of vegetables belonging to the tropical, subtropical and temperate zones are cultivated. They are grown right from the sea level to the snow line under varied agro-ecological conditions. The area under vegetable alone stood at 10.1 million hectares and produced around 189 million metric tons during the year 2019-20 which accounts for nearly 11.0 per cent of the country's share in the world total production of vegetables (NHB, 2020). Hills of India are impart with variability and diversity of highly localized agricultural system for cultivation of number of vegetables. Jammu \& Kashmir UT is known for its climate and weather which is favourable for production of vegetables both normal and offseason, and this availability makes the produce available throughout the year to the consumers of $\mathrm{J} \& \mathrm{~K}$ and adjoining areas. Union Territory of Jammu and Kashmir is having agriculture as the leading area in its economy where more than 70 percent of the population depends on it directly or indirectly. It also contributes about 60 per cent of revenue of Union Territory. Diversification of agriculture from traditional cereal based system to vegetables cultivation compatible with the comparative advantage of the region is the only viable solution to stabilize and raise farm income and increase employment opportunities (Joshi et al. 2004). The per capita availability is less than the prescribed requirement $200 \mathrm{gms}$ per person per day and to address the excess demand the vegetables are imported from outside J\&K. 1.99 lakh metric tons of vegetables have been imported ending November 2014. The area under vegetable crop in Jammu region during the year 2017-18 was 27,531 hectares with a production of about 706,307.86 metric tons.

\section{Objectives}

1. To find out the costs and returns analysis of selected vegetable crops in Arnia block.

2. To assess the value chain analysis of selected vegetable crops in Arnia block.

\section{MATERIALS AND METHODS}

\section{Locale of the study}

The current study was conducted in the Arnia block of Jammu districts of Jammu \& Kashmir UT.

\section{Sampling design}

For sample selection, a multi-stage random sampling design was used, with districts, villages, and vegetable producers as the first, second and third stage units, respectively.

(i) Selection of blocks: Fifty percent blocks from Jammu district comprising of ten in number were selected on the basis of highest area under vegetable crops.

(ii) Selection of villages: two villages from each block were selected randomly to constitute twenty villages in total.

(iii) Selection of vegetable growers: A complete list of vegetable growers in the randomly selected villages was compiled along with their land holdings. A proportionate allocation approach is used to select 240 farmers at random from the sampled villages. The formula that was used to choose farmers from the sample villages is given below:

$$
n i=N i / N \times n
$$

Where,

$n i=$ Number of farmers to be sampled in $i^{\text {th }}$ villages; $N i=$ Total number of farmers in $i^{\text {th }}$ villages; $N=$ Total number of farmers in all the selected villages; $n=$ Total sampled size to be choosen.

Therefore, the sample size is comprised of 240 vegetable growers from the whole area under study.

\section{RESULTS AND DISCUSSION}

This chapter proceeds with data analysis and discussion of the results obtained from the survey done in Jammu district of Jammu and Kashmir UT.

\section{COST AND RETURNS}

\section{Item wise cost structure for vegetable cultivation}

The operation wise cost of cultivation of vegetables 
in the Arnia block is presented in Table 1. It shows that in Arnia block, three major crops were grown by the farmers viz. Cabbage, Cauliflower and Tomato and per hectare total cost of cultivation in Cabbage, Cauliflower and Tomato were found to be ₹ 46,981.96, ₹ 46,864.53 and ₹ 49,844.12, respectively. Expenditure on human labour, seed and Farm yard manure (FYM) were the important component of operational cost. Similarly rent paid for leased in land was the most important component of fixed cost. The results further revealed that out of all the inputs used, the expenditure incurred on machine labour was found to be highest with ₹ 5000.00/ha followed by manures and fertilizers ( $₹ 7700.00 / \mathrm{ha}$ ). However on overall basis, the operational cost was ₹ $38,903.07$, ₹ $38,191.64$, ₹ $41,171.23$ per hectare and fixed cost was ' 8672.89 per hectare. Among the various crops grown in the study area the highest cost was incurred in the cultivation of tomato ₹ 30056.00/ha and least cost was incurred in the cultivation of cabbage ₹ 49844.12/ha. The operation wise cost of cultivation of vegetables in Miran Sahib block is presented in (Table 1) it shows that in Miran sahib block three major crops viz Cabbage, Cauliflower and Knolkhol were grown by the farmers. The table revealed that per hectare total cost of cultivation in Cabbage, Cauliflower and Knol-khol was ₹ 48,725.31, ₹ 46,879.15 and ₹ 49,212.40, respectively. Expenditure on human labour, seed and Farm yard manure (FYM) were the important component of operational cost. Similarly rentpaid for leased in land and depreciation were the most important component of fixed cost.

Table 1: Item-wise cost of cultivation of vegetable in Arnia block (₹/ha)

S1.

No. Particulars

\section{A. Operational cost}

I Machine labour

II Human labour Hired labour

Family labour

Total human labour

III Seed/seedlings

IV Fertilizers

V FYM

VI Plant protection

VII Irrigation charges

VIII Interest on working capital

\section{Arnia}

Cabbage Cauliflower Tomato

$5000.00 \quad 5000.00 \quad 5000.00$

$\begin{array}{lll}3352.50 & 4352.50 & 5350.50 \\ 9000.00 & 9000.00 & 9600.00 \\ 12352.50 & 13352.50 & 14950.50 \\ 3515.00 & 2858.00 & 2000.00 \\ 7000.00 & 6700.00 & 6000.00 \\ 4570.00 & 4500.00 & 3500.00 \\ 2937.50 & 2850.60 & 6700.60 \\ 1782.20 & 1782.20 & 1782.20\end{array}$

$1151.87 \quad 1148.34$

1237.93

\begin{tabular}{lllll} 
IX & $\begin{array}{l}\text { Subtotal (A) } \\
\text { (from I to VIII) }\end{array}$ & 38309.07 & 38191.64 & 41171.23 \\
\hline B. & Fixed cost & & & \\
\hline$X$ & $\begin{array}{l}\text { Rental value of } \\
\text { owned land (net of } \\
\text { land revenue) }\end{array}$ & 140.00 & 140.00 & 140.00 \\
XI & $\begin{array}{l}\text { Rent paid for leased- } \\
\text { in land }\end{array}$ & 2600.00 & 2600.00 & 2600.00 \\
XII & $\begin{array}{l}\text { Depreciation on } \\
\text { farm buildings and } \\
\text { equipments }\end{array}$ & 5645.00 & 5645.00 & 5645.00 \\
XIII & $\begin{array}{l}\text { Interest on fixed } \\
\text { capital }\end{array}$ & 287.89 & 287.89 & 287.89 \\
\hline & $\begin{array}{l}\text { Sub -Total (B) } \\
\text { (from X to XIII) }\end{array}$ & 8672.89 & 8672.89 & 8672.89 \\
& & & \\
Total cost (A +B) & 46981.96 & 46864.53 & 49844.12 \\
\hline
\end{tabular}

\section{Concept-wise cost structure of vegetable cultivations}

In order to view the cost of cultivation of vegetables, various cost concepts worked out in Arnia block on per hectare basis and are presented in Table 2. Per hectare cost $A_{1}$ in cabbage, cauliflower and tomato was found to be ₹ 34954.22, ₹ 34836.64, and ₹ 37216.23, Human labour, machine labour, seed and seedlings, manures and fertilizers were the main components of cost $A_{1}$. Cost $A_{2}$ incurred in cabbage, cauliflower and tomato were ₹ 37554.20/ ha, ₹ 37436.64/ha, and ₹ 39816.23/ha, respectively. Similarly, per hectare cost $B_{1}$ was $₹ 35242.11$, ₹ 35124.53, and ₹ 37504.12, respectively whereas cost $B_{2}$ was $₹ 37982.11$, ₹ 37864.53 and $₹ 40244.12$, respectively. The table further revealed that per hectare cost $C_{1}$ was found to be $₹ 44242.11$, ₹ 44124.53, and ₹ 46504.12, respectively in case of cabbage, cauliflower and tomato per hectare cost $\mathrm{C}_{2}$ was found to be $₹ 46982.11$, ₹ 46864.53, and $₹ 49244.12$, respectively. After working out management cost, i.e., 10 percent of cost $C_{2}$, per hectare cost $C_{3}$ was found to be $₹ 49780.80$, ₹ 49768.00, and ₹ 50726.20, respectively.

Table 2 : Concept-wise cost of cultivation of vegetables in Arnia block of Jammu district (₹/ha)

\begin{tabular}{|c|c|c|c|}
\hline \multirow{2}{*}{ Particulars } & \multicolumn{3}{|c|}{ Arnia } \\
\hline & Cabbage & Cauliflower & Tomato \\
\hline \multicolumn{4}{|l|}{ Cost- $A_{1}$} \\
\hline Hired labour & 3352.50 & 4352.50 & 5350.50 \\
\hline Machine labour & 5000.00 & 5000.00 & 5000.00 \\
\hline FYM & 4570.00 & 4500.00 & 3500.00 \\
\hline Seed/seedlings & 3515.15 & 2858.00 & 2000.00 \\
\hline
\end{tabular}




\begin{tabular}{|c|c|c|c|}
\hline Fertilizers & 7000.00 & 6700.00 & 6000.00 \\
\hline Plant protection & 2937.50 & 2850.60 & 6700.60 \\
\hline Irrigation charges & 1782.20 & 1782.20 & 1782.20 \\
\hline $\begin{array}{l}\text { Interest on working } \\
\text { capital }\end{array}$ & 1151.87 & 1148.34 & 1237.93 \\
\hline Depreciation charges & 5645.00 & 5645.00 & 5645.00 \\
\hline Total cost $-\mathrm{A}_{1}$ & 34954.22 & 34836.64 & 37216.23 \\
\hline Cost $-\mathrm{A}_{1}$ & 34954.22 & 34836.64 & 37216.23 \\
\hline $\begin{array}{l}\text { Rent paid for leased in } \\
\text { land }\end{array}$ & 2600.00 & 2600.00 & 2600.00 \\
\hline Total cost $-\mathrm{A}_{2}$ & 37554.2 & 37436.64 & 39816.23 \\
\hline Cost- $\mathrm{A}_{1}$ & 34954.22 & 34836.64 & 37216.23 \\
\hline $\begin{array}{l}\text { Interest on fixed capital } \\
\text { (excluding land) }\end{array}$ & 287.89 & 287.89 & 287.89 \\
\hline Total cost- $\mathrm{B}_{1}$ & 35242.11 & 35124.53 & 37504.12 \\
\hline Cost-B ${ }_{1}$ & 35242.11 & 35124.53 & 37504.12 \\
\hline $\begin{array}{l}\text { Rental value of owned } \\
\text { land }\end{array}$ & 140.00 & 140.00 & 140.00 \\
\hline $\begin{array}{l}\text { Rent paid for leased in } \\
\text { land }\end{array}$ & 2600.00 & 2600.00 & 2600.00 \\
\hline Total cost-B ${ }_{2}$ & 37982.11 & 37864.53 & 40244.12 \\
\hline Cost-B $B_{1}$ & 35242.11 & 35124.53 & 37504.12 \\
\hline Family labour & 9000.00 & 9000.00 & 9000.00 \\
\hline Total cost- $\mathrm{C}_{1}$ & 44242.11 & 44124.53 & 46504.12 \\
\hline Cost-B ${ }_{2}$ & 37982.11 & 37864.53 & 40244.12 \\
\hline Family labour & 9000.00 & 9000.00 & 9000.00 \\
\hline Total cost- $\mathrm{C}_{2}$ & 46982.11 & 46864.53 & 49244.12 \\
\hline Cost- $\mathrm{C}_{2}$ & 46982.11 & 46864.53 & 49244.12 \\
\hline $\begin{array}{l}\text { Cost of management } \\
\left(10 \% \text { of Cost- } C_{2}\right)\end{array}$ & 4698.21 & 4686.45 & 4924.41 \\
\hline otal cost- $\mathrm{C}_{3}$ & 49780.80 & 49768.00 & 50726.20 \\
\hline
\end{tabular}

Cost and return structure of Vegetables in Arnia block of Jammu district

Table 3: Cost and returns of vegetables of Arnia block farms under study (₹/ha)

\begin{tabular}{llll}
\hline \multirow{2}{*}{ Particulars } & \multicolumn{3}{c}{ Arnia } \\
\cline { 2 - 4 } & Cabbage & Cauliflower & Tomato \\
\hline Cost & & & \\
\hline Total variable cost & 38309.07 & 38191.64 & 41171.23 \\
Total fixed cost & 16358.70 & 16158.70 & 16058.70 \\
Total cost & 46981.96 & 46864.53 & 49844.12 \\
\hline Returns & & & \\
\hline Yield (quintal) & 250.00 & 200.00 & 125.00 \\
Price/q & 600.00 & 700.00 & 1500.00 \\
Gross returns/ha & 150000.00 & 140000.00 & 187500.00 \\
Net returns & 103018.00 & 93135.47 & 137655.9 \\
Cost-Benefit Ratio & $1: 3.19$ & $1: 2.99$ & $1: 3.76$ \\
\hline
\end{tabular}

Per hectare Cost and return analysis of vegetables in Arnia block on all the sampled vegetables were analyzed and are presented in Table 3, which revealed that, the total cost of cultivation was highest in tomato (₹ 49844.12/ha) followed by cabbage ( $₹ 46981.96 \mathrm{R} / \mathrm{ha}$ ) and cauliflower (₹ 46864.53/ha). Gross returns were highest in the farms of tomato (₹ 187500/ha) followed by cabbage ( $₹$ 150000.00/ha) and least in cauliflower (₹ 140000.00/ ha). The net returns per hectare were found to be highest in tomato (₹ 137655.9/ha) followed by cabbage (₹ 103018.00/ha) and cauliflower (₹ 93135.47/ha). The cost benefit ratio was found to be highest in tomato (1:3.76) and least in cauliflower (1:2.09).

\section{Marketing of Vegetables}

In planned economic development, exchange of goods play a very important role in maintaining equilibrium between production and consumption. The prosperity of the cultivators thus depends not only on the increased rate of production, but also upon the method and efficiency with which they dispose of their produce to the great advantage.

Table 4: Vegetable wise marketing cost and price spread analysis in Arnia Block (₹/q)

\begin{tabular}{lc}
\hline & $\begin{array}{c}\text { Channel }- \text { I: Producer } \rightarrow \\
\text { Forwarding/ Commission Agent } \\
\text { Particulars }\end{array}$ \\
& Wholesaler $\rightarrow$ Retailer $\rightarrow$ \\
Consumer
\end{tabular}

\begin{tabular}{|c|c|c|c|}
\hline & Tomato & Cabbage & Cauliflower \\
\hline Producer's sale price & 1500.00 & 600.00 & 700.00 \\
\hline \multicolumn{4}{|l|}{ Producer's expenses } \\
\hline $\begin{array}{l}\text { Cost of gunny bags/ } \\
\text { crates }\end{array}$ & 250.00 & 70.00 & 70.00 \\
\hline Transport & 50.00 & 100.00 & 119.26 \\
\hline Loading/unloading & 20.00 & 40.00 & 41.00 \\
\hline $\begin{array}{l}\text { Commission @7\% } \\
\text { by Forwarding/ } \\
\text { Commission Agent }\end{array}$ & 105.00 & 42.00 & 49.00 \\
\hline Total costs & 425.00 & 252.00 & 279.26 \\
\hline Net sale price & 1075.00 & 348.00 & 420.74 \\
\hline \multicolumn{4}{|l|}{ Wholesaler's level } \\
\hline Purchase price & 1500.00 & 600.00 & 700.00 \\
\hline $\begin{array}{l}\text { Wholesaler's } \\
\text { expenses }\end{array}$ & - & - & - \\
\hline Transport & 80.00 & 100.00 & 100.00 \\
\hline Loading/unloading & 40.00 & 50.00 & 50.00 \\
\hline Repair of packing & 20.00 & 20.00 & 20.00 \\
\hline
\end{tabular}




\begin{tabular}{|c|c|c|c|}
\hline Total cost & 140.00 & 170.00 & 170.00 \\
\hline Sale price & 2500.00 & 1500.00 & 1700.00 \\
\hline $\begin{array}{l}\text { Net sale price of } \\
\text { wholesaler }\end{array}$ & 2360.00 & 1330.00 & 1530.00 \\
\hline $\begin{array}{l}\text { Marketing margin of } \\
\text { wholesaler }\end{array}$ & 860.00 & 730.00 & 830.00 \\
\hline Retailer's level & - & - & - \\
\hline Purchase price & 2500.00 & 1500.00 & 1700.00 \\
\hline Retailer's expenses & - & - & - \\
\hline Loading/unloading & 70.00 & 60.00 & 60.00 \\
\hline Transport & 100.00 & 100.00 & 100.00 \\
\hline Rehri/ Shop rent & 20.00 & 20.00 & 20.00 \\
\hline $\begin{array}{l}\text { Spoilage due to } \\
\text { physical injury and } \\
\text { rotting, etc. (PHL) }\end{array}$ & 20.00 & 0.00 & 0.00 \\
\hline Total costs & 210.00 & 180.00 & 180.00 \\
\hline Sale Price & 3500.00 & 2500.00 & 2750.00 \\
\hline $\begin{array}{l}\text { Net sale price of } \\
\text { retailer }\end{array}$ & 3290.00 & 2320.00 & 2570.00 \\
\hline $\begin{array}{l}\text { Marketing Margin of } \\
\text { retailer }\end{array}$ & 790.00 & 820.00 & 870.00 \\
\hline $\begin{array}{l}\text { Total Marketing } \\
\text { Margin }\end{array}$ & 1650.00 & 1550.00 & 1700.00 \\
\hline Consumer price & 3500.00 & 2500.00 & 2750.00 \\
\hline $\begin{array}{l}\text { Producers' share in } \\
\text { consumers' rupee } \\
\text { (percent) }\end{array}$ & 42.85 & 24.00 & 25.45 \\
\hline
\end{tabular}

In general, marketing constitute the expenses on the items like container cost, filling, packing, transportation, carry bags cost and other charges. These costs are the actual expenditure incurred for the smooth running of business as well as for efficient marketing of particular farm commodity. The Table 4 represents the channel and vegetable wise marketing cost and price spread analysis in Arnia block of Jammu district. In this district the farmers sell their produce in the market following the channel-1 i.e. Producer $\rightarrow$ Forwarding/Commission Agent $\rightarrow$ Wholesaler $\rightarrow$ Retailer $\rightarrow$ Consumer. Marketing cost at producer's level included cost of containers, transportation cost, cost of carry bags and labour charges. These costs varied to the extent of ₹ 425.00, ₹ 252.00 and ₹ 279.26 per quintal for tomato, cabbage and cauliflower, respectively. Apart from that, container charges in case of tomato and transportation charges in case of cabbage and cauliflower also made a considerable share in the marketing cost incurred at producer's level i.e., ₹ 250.00 and ₹ 70.00 per quintal, respectively. As far as the wholesaler's and retailer's marketing cost was concerned, it was found that wholesaler had incurred only ₹ 140.00 per quintal in marketing of tomato and ₹ 17000 per quintal in both cabbage and cauliflower whereas retailer had incurred ₹ 210.00 per quintal in tomato and ₹ 180.00 per quintal in both cabbage and cauliflower. Per quintal marketing margins realized at wholesaler levels were ₹ 860.00, ₹ 730.00 and ₹ 830 for tomato, cabbage and cauliflower, respectively whereas at retailer's level these were found to be ₹ 790.00, ₹ 820.00 and ₹ 870, respectively. Post harvest loss was found in tomato only to the tune of ₹ 20.00 per quintal. The vegetable growers of Arnia block received the net price of ₹ $1075.00 / \mathrm{qtl}$, ₹ 348.00/qtl, and ₹ 420.74/qtl in tomato, cabbage and cauliflower, respectively. Maximum sale price at producer's level was found in tomato which was to the tune of ₹ 1500.00 per quintal. The wholesalers' sale price to retailer was ₹ $2500.00 / q$, ₹ $1500.00 / q$ and ₹ $1700.00 / q$ in tomato, cabbage and cauliflower, respectively. Similarly, the retailers' sale price which is also called as purchase price of consumer was found to be ₹ $3500.00 / q$, ₹ $2500.00 / q$ and $₹ 2750.00 / q$, respectively for all the three vegetables. The producers share in consumer rupee was found to be highest in tomato to the tune of 42.85 per cent followed by cauliflower 25.45 per cent and cabbage 24.00 per cent.

\section{CONCLUSION}

1. Farmers in the Arnia block grew three major crops: cabbage, cauliflower, and tomatoes. The findings revealed that, of all the inputs used, the spending on human labour was the greatest. The results regarding cost structure of vegetable cultivation in Arnia block (Table 4.6) witnessed the largest cost which is incurred in tomato growing and the lowest cost was incurred in cabbage cultivation.

2. The total cost of cultivations in the Arnia block was highest in tomato and lowest in cauliflower. The tomato yielded the highest gross return, while cabbage yielded the lowest. The total gross income from all of the veggies was ₹ 121416.66 per hectare. The highest net returns per hectare was observed in tomatoes, while the lowest was observed in cabbage. The cost-benefit ratio was highest for tomato and lowest for cabbage, according to the results. 
3. In Arnia block farmers follows channel- I to sell their produce in the market such as tomato, cabbage, and cauliflower. The container expense ate up the majority of the marketing cost. Aside from that, transportation expenditures made up a considerable portion of the producer's marketing costs. Retailer's received highest margins in tomatoes, while cauliflower received the lowest at retailer level. Tomatoes have the highest producer share in consumer rupee, whereas cauliflower has the lowest. The total marketing margin was highest in cauliflower, while it was observed lowest tomato. Results related to the Transportation costs accounted up the majority of marketing costs at the producer and retailer levels,

\section{REFERENCES}

Joshi, P.K., Gulati, A., Prata, Birthal, S. and Laxmi. T. 2004. Agricultural Diversification in South Asia Patterns. Determinants and Policy Implications. J. Eco. Pol. Week, 9(24): 2457-2467

Shahbandeh, M. 2021. Leading global producers of fresh vegetable 2020. Agriculture Farming. www.statistica.com

www.worldometer.info assessed on 15.07.2021. 